\title{
An Econometric Analysis of the Nexus of Exchange Rate, Inflation and Budget Deficit: Case of Nigeria 1981 - 2016
}

\author{
Suleiman Sa'ad, Alexander Abraham, Olure-Bank Adeyinka Michael* \\ Department of Economics, Faculty of Social Sciences, Nigeria Defence Academy, Kaduna, Nigeria \\ Email address: \\ Suleimansa'ad@gmail.com (Suleiman S.), abrahamlex2@gmail.com (Alexander A.), adeyinka67@gmail.com (Olure-Bank A. M.), \\ nikeolure@yahoo.co.uk (Olure-Bank A. M.) \\ ${ }^{*}$ Corresponding author
}

\section{To cite this article:}

Suleiman Sa'ad, Alexander Abraham, Olure-Bank Adeyinka Michael. An Econometric Analysis of the Nexus of Exchange Rate, Inflation and Budget Deficit: Case of Nigeria 1981 - 2016. Journal of World Economic Research. Vol. 7, No. 1, 2018, pp. 1-13.

doi: $10.11648 /$ j.jwer.20180701.11

Received: December 18, 2017; Accepted: January 3, 2018; Published: January 19, 2018

\begin{abstract}
Depreciation of the naira has a role to play in Nigeria's recent inflationary process. Concomitant with this is the substantial budget deficit operated annually by the Federal Government in the last decade or so. Part of the budget deficit is finance through bank credit which directly affects the money base. This also exerts upward pressure on the general price level. All this suggests that there are many sources of the current inflation. While the channels through which exchange rate depreciation affects prices are known, the extent to which this phenomenon engenders price inflation in Nigeria is still not well researched. As part of the attempt to fill this gap, this study examines the quantitative effects of exchange rate depreciation on budget deficit and inflation in Nigeria. This is achieved in two stages. First, a structural model of the interaction between exchange rate, budget deficit, inflation, and government revenue and expenditure is constructed. In doing this, the study is influenced by SVAR cointegration and the error correction model. This result presents trends in the relationship between exchange rate, budget deficit and inflation and the impact exchange rate on inflation and budget deficit are positive but not statically significant and incomplete. The findings from this study have a number of policy implications for Nigeria government. A major policy implication of the results of the study is that concerted effort should be made by the Nigeria's government to strengthen the production capacity of domestic firms and industries in order to reduce the level of the imported consumer and capital goods. This will help improve the level of exchange rate impact on other macroeconomic variables in Nigeria.
\end{abstract}

Keywords: Foreign Exchange Rate Pass Through, Consumer Price, Budget Deficit, Cointegration

\section{Background to the Study}

Exchange rate is one of the important macroeconomic variables used for determining the strength of international competitiveness among trading countries. It is being regarded as an indicator of competitiveness of domestic currency of any country. Arguably, the lower the value of the exchange rate currency of any country, higher the competitive advantage of the currency of that country over its trading partner's currency. However in Nigeria, it is not so due to inability to produce exports competitively. Prior to the adoption of Structural Adjustment Programme (SAP) and exchange rate policy reforms in Nigeria, overvaluation of currency was not regarded as a serious problem in Nigeria.
Overvaluation is a deliberate act, when government allows the value of its exchange rate to appreciate with a wrong notion to maximize growth and development. Overvaluation could also arise from increase in consumer price index if the increase is not adjusted to exchange rate. Overvaluation of a currency is when the domestic currency assumes a higher value in relation to other currencies. (Killick, 1992) [1], that bring about distortion of the economy. It crowd out local production and encourages importation; as import become relatively cheaper, as local currency cost of importation will be kept artificially low and discourages export by reducing the profitability of producing for world markets as prices of exports become relatively dearer in the international market. It is been argued that the combine effect of increasing 
importation and dwindling exports exerts pressure on the balance of trade and the economy at large. Zubair and Sanusi (2013) [2]. In the era of globalization, appropriate policy mix that ensures an effective rate of exchange is imperative because its variation has economic implications. Variation in exchange rate is an important endogenous factor that affects economic performance, due to its impact on macroeconomic variables like inflation rate and budget deficit. A sound exchange rate policy and an appropriate exchange rate are crucial conditions for improving economic performance Chang and Tan (2008) [3]. In Nigeria, Foreign exchange rate regime and inflationary trend has been cyclical since early 1970s peaking at various times $(1975,1990,1996,2000$ and 2014). One major factor that has been responsible for fluctuations in Nigeria is poor RER management. Real exchange rate in Nigeria has continued to be viewed as a matter of national and international concern. A stable system of exchange rate is seen as dependent on stable macroeconomic policies at the national level. The poor economic performance in the recent years shows that the exchange rate system has created serious economic problem. The most serious problem has been that of the RER movements (i.e NER adjusted for inflation differences across countries) have gone far beyond those suggested by economic theories. Such maladjustments have created a major economic problem in Nigeria. Arguably it has prevented efficient allocation of resources. Large RER changes of over 100 percent over the medium term adversely affect the pattern of production, employment investment and consumption within Nigeria. It is often argued that RER instability has adverse effects on economic growth, because it creates uncertainty (which reduces investment) causes resources to move back and forth between tradable and nontradable and more generally generates unnecessary adjustment costs (El Rasheed Shehu 2000) [4]. The implication is that instability is not predictable thereby causing distortion in private and public sectors planning decisions.

The broad objective of this study is to examine the effect of exchange rate on inflation and budget deficit in Nigeria over the period 1981 - 2016. The specific objectives are as follows:

(i) To investigate how real exchange rate pass-through to domestic prices in the Nigerian economy over the period of study.

(ii) To determine the relationship among RER, inflation, and budget deficit over the period of study.

With regard to the above objective and problem of RER instability in Nigeria, the following questions are considered significant for this study.

i. Does the real exchange rate pass impact domestic prices in the Nigerian economy over the period of study?

ii. What are the relationship among RER, inflation, and budget deficit over the period of study?

In an attempt to address this and other related questions on RER instability implication in Nigeria. The following null hypotheses will be tested in the course of this study:
$\mathrm{H}_{\mathrm{ol}}$ : Real exchange rate does not impact domestic prices in the Nigerian economy over the period of study.

$\mathrm{H}_{\mathrm{o} 2}$ : There is no relationship among RER, inflation, and budget deficit over the period of study.

This is particularly germane given that with the country's huge potentials in many sectors of the economy, coupled with its natural resources endowment; it has had to struggle with the challenges of poverty, unemployment and underdevelopment. An empirical investigation of exchange rate policy implications on inflation and budget deficit will be helpful to economic planners, researchers and policies maker not only in the country but in other developing and emerging countries in terms of the degree to which exchange rate depreciation can move their production possibility frontier upwards and enhance international competitiveness of their products. This then makes a study of this nature a very useful contribution to the existing knowledge.

The study uses time series secondary data covering 19812016. The choice of 1980 was on the basis that, although active exchange rate policy was adopted in the early $1970 \mathrm{~s}$ following the decimalization and change of the Nigeria currency from the pound to naira, depreciation of naira never becomes a problem in Nigeria until in the 1980s. The following variables money supply, real GDP and its deflator, consumer price index, and official exchange rate, government revenues and expenditures, internal and external debt, debt service payments and the parallel market exchange rate are obtained from the statistical Bulletin of the Central Bank of Nigeria $(\mathrm{CBN})$ publications: and the National Bureau of Statistics (NBS).

This paper is organized into five sections. Following the introduction, section two briefly reviews related studies. In Section three, the model to be estimated is presented. Section four discusses the findings of the analyses, while Section five are concludes and recommendations of the paper.

\section{Conceptual, Theoretical and Empirical Literatures}

\subsection{Conceptual Review}

Exchange rate has been defined as the price of one currency in terms of another currency Mordi (2006) [5]. Exchange rate is the price at which one country exchanges its currency for other currencies. The increase or decrease of real exchange rate indicates strength and weakness of currency in relation to foreign currency and it is a standard for illustrating the competitiveness of domestic industries in the world market Razazadehkarsalari, Haghiri and Behrooznia, (2011) [6].

Inflation can mean either an increase in the money supply or a persistent increase in price levels. Generally, when we hear about inflation, we are talking about a persistent rise in prices compared to some benchmark. If the money supply has been increased, this will usually manifest itself in higher price levels - it is simply a matter of time. Thomas (2006) [7]

When the government expenditure exceeds revenues, the 
government is having a budget deficit. Thus the budget deficit is the excess of government expenditures over government receipts (income). When the government is running a deficit, it is spending more than its receipts. Government finances deficit mainly by borrowing from the public, through selling bonds, it is also financed by borrowing from the Central Bank.

\subsection{Theoretical Framework}

Exchange rate pass through signifies the level to which exchange rate changes are passed on to the local currency prices of traded goods. Goldberg and Knetter (1997) [8], Mumtaz et al. (2006) [9], defined exchange rate pass through as "percentage change in the local currency import prices resulting from a one per cent change in the exchange rate between the exporting and the importing countries. Similarly, Campa and Goldberg (2002) [10], pass-through studies considered the degree to which exchange rate movements are passed into traded goods consumer prices, versus absorbed in producer profit margins. Lafleche (1996) [11] indicated that exchange rate transmits to consumer price directly and indirectly.

Theoretical framework to be adopted in study is a linkages between exchange rate and budget deficit, on the one hand, and between each of these variables and inflation, on the other, and it is relatively straight-forward. This section sketches only the principal channels, beginning with the channels of transmission between exchange rate and inflation.

The 'pass through' argument is usually the basis on which the inflationary tendencies of exchange rate devaluation are premised. This is predicate on the assumption that the induce increases in the prices of import inputs, semi goods and final goods, following a devaluation of the local currency, will be pass on to domestic prices. From this, it is obvious that this proposition has its roots in the cost-push theory of inflation. This is not to deny that theoretical and empirical strand of the literature which is predicated on the purchasing power parity (PPP) doctrine which is examine in (Sanusi 2010, [12] Ogundipe and Egbetokun 2013) [13].

Arguably, there is high dependence on import inputs for production by most developing countries Nigeria inclusive. When there is devaluation, the domestic prices of imported inputs are raised and production costs are accordingly affected. Profits plus indirect taxes are usually mark-ups on producer prices to obtain ex-factory prices (and ex-factory prices plus distributor's margins equal market prices). In this sense, prices are formed on the basis of mark-up over cost of production. A highly simplified model of this is often represented.

$$
\mathrm{P}=\mathrm{M}\left(\mathrm{W}+\mathrm{eP}^{*}\right)
$$

Where; P represents the output price,

$\mathrm{M}$ stands for 1 plus the fixed mark-up rate,

$\mathrm{W}$ is the wage rate,

e denotes exchange rate and is the foreign price of imported inputs.

The above equation assumes a constant mark-up. But the argument has been advanced that the size of the mark-up is largely a function of excess demand in the economy. (Chhibber 1989) [14].

The rise in the general price level engendered by devaluation usually triggers a series of developments that often fuel the inflationary process. Even the rise in domestic prices without a corresponding increase in nominal wage rate reduces the real wage and a household has to spend more in order to maintain the same living standard. There is the tendency for labour to agitate for increases in wages and benefits. When such demands are granted, production costs and therefore, market prices are affected accordingly. Of course, this is not inevitable if labour productivity increases correspondingly.

Arguably, most developing countries including Nigeria, the government is the major employer of labour and as such, increases in wages have a tendency to raise public outlays: the rise in government expenditure generates budget deficit when the revenue collected is inadequate to meet the expansion in expenditures. This leads us to budget deficitinflation relationships. The channels of transmission between budget deficit and inflation are easily appreciated when the deficit is financed, in part, from increased Central Bank credit to the government. Two immediate direct effects of this can be identified. The increase in bank credit to the public sector expands aggregate demand and enhanced public expenditure has a tendency to raise private sector income and, therefore, demand for goods and services via the multiplier process. For a developing country (Nigeria) that has a domestic limited supply of goods and services, the expansion in aggregate demand tends to exceed supply and a sustained rise in the general price level inevitably results.

The second effect is easily understood and domestic money supply is central to this. The growth of bank credit directly influences the growth of the money base (i.e., highpowered money) which, in turn, expands the growth of the money supply. The direct correspondence between money and price inflation is well known. Even within this monetary framework, it has been argued that the existence of an excess supply of real money balances directly stimulates real private expenditure in turn inflation.

We now explore the relationship between the exchange rate and budget deficits. This task has been simplified by the work of Chhibber (1989) [14]. Exchange rate movements simultaneously affect both the revenue and expenditure sides of the budget. When there is devaluation, for instance, external debt and debt service payments in domestic currency rise. Thus, a component of the overall public expenditure is increased.

Theoretically, elasticity approach to balance of payments states that devaluation of home currency leads to an increase in exports, decrease in imports and thereby improvement in the balance of payments situation of the devaluing country. However, on the contrary, the popular J-curve hypothesis states that devaluation of the home currency leads to 
deterioration of the balance of payments of the devaluing country initially due to the increase in the value of imports compared to the increase in the value of exports; the balance of payments improves only in the long-run due to the operation of lag effects coming from devaluation. Because devaluation stimulates the production of exports, it raises the income of exporters and subsequently increases revenue generated from taxes (Corden, 1989) [15]. Revenues from export duties rise with increased export production consequent upon devaluation of the exchange rate. The extent to which the volume of import decreases is a function of the price elasticity of demand. But Corden (1989) [15] argued that a devaluation of the exchange rate raises the domestic currency value of government imports. Changes in the level of imports affect revenue realised from customs duties.

It follows from this that the net effect of exchange rate movements on the budget is largely a function of tax structures and expenditures. If the net effect be fiscal deficit that is monetized, inflation will result. Both government expenditure and revenue adjust to inflation disproportionately and an enlarged budget deficit is generated if expenditure responds faster than revenue. Perhaps this discussion presents the two-way causality between inflation and budget deficit, as they feed on each other through what is referred to in the literature as the Keynes-Olivera-Tanzi effect (Tanzi, 1977) [16].

\subsection{Empirical Review}

At any rate, empirically, in the work of Chuba (2015) [17], he explored to determine the effect of exchange rate changes on consumer prices in Nigeria by the using recursive vector autoregressive model. He used data from first quarter 2000 to fourth quarter 2013. The findings of the study showed that exchange rate fluctuation had a positive and insignificant effect on consumer prices and the increase in consumer prices was mainly due to its own shocks and the increase in money supply in the long run. He believed that stable monetary policy with a low inflationary environment will reduce the pressure of exchange rate changes on consumer prices. Therefore, he recommended that Central Bank of Nigeria should be less concern with the inflation impact of exchange rate shocks and focus fully on other objectives such as growth and export competitiveness in designing exchange rate policy.

Also, Fatai and Akinbobola (2015) [18] in their work investigated the impact of Exchange Rate Pass-through to import prices, Inflation, and monetary policy in Nigeria. Secondary data were used. The data covered the period of 1986-2012. They used annual data on Nominal Effective Exchange Rate Index, Import Prices, Interest Rate, Money Supply and Inflation were sourced from the publication of the Central Bank of Nigeria $(\mathrm{CBN})$ and Oil Price Index were sourced from the World Development Indicators published by the World Bank. The study applied Six-Variable vector autoregressive model to estimate the impulse response function and variance decomposition. In their study, they found out that exchange rate pass-through in Nigeria during the period they reviewed was moderate, significant and persistent in the case of import prices and low and short lived in the case of inflation. In addition, they equally found that exchange rate pass-through was incomplete and has useful implication to policymakers, especially in the design and implementation of exchange rate and monetary policy. Thus, they recommended that policy makers should take into account the incomplete response of import prices when they decide to devalue the currency so as to improve trade balance irrespective of several other factors which might determine the effectiveness of exchange rate policy.

In another study, Ude and Anochie (2014) [19] examined the relationship between exchange rate pass-through, monetary policy and price stability in Nigeria. The study adopted the multi-linear regression model. From their findings, it can be reasonably concluded that general price level is unstable vis a vis nominal exchange rate in Nigeria which inhibits one-to-one exchange rate pass-through. However, the general lesson that emerged from the study was that exchange rate pass-through and implementation capacity are important, especially for determining the effectiveness of exchange rate pass-through on monetary policy and price stability in Nigeria. The study therefore recommended that monetary policy authorities should elect for appropriate exchange rate regime to be able to stabilize exchange rate, domestic import prices and consumer price index. Appreciation of the exchange rate would prove effective in improving Nigeria"es external reserve.

More so, Aliyu et al (2013) [2] estimated the exchange rate pass-through to domestic prices in Nigeria using structural vector autoregressive approach. The major finding of the study is that exchange rate pass-through in Nigeria is incomplete and low. Secondly, that the total impact is attained after eight quarters, suggesting that it is quiet slow. The interpreted the low and slow exchange rate pass-through to mean that exporters to Nigeria practice a substantial degree of pricing-to-market strategy. This suggests that instead of allowing the naira price of their products to vary whenever there are changes in the exchange rate, these firms allow their mark-ups to vary as they change their local currency prices in the opposite direction of the change in exchange rate. They argued that this is plausible in Nigeria being a large market for fairly all its imported commodities. Therefore, firms would therefore strive to keep their competitive advantage in the domestic market as exchange rate changes. This explains the low pass-through observed. One implication of their findings is that the cost of true float may not be as large as it would under complete pass-through, therefore a good potential for de facto float, since only a small fraction of the excessive variations in the exchange rate that such a regime would entail will be passed onto inflation.

In addition, Ogundipe and Egbetokun (2013) [13] investigated the exchange rate pass-through to consumer prices for Nigeria using the vector error correction model approach. The approach was used to address specific features of the Nigeria economy, especially the import dependence 
nature and the role of foreign exchange inflows in the conduct of monetary policy. The degree of exchange rate pass-through was estimated by means of impulse response function from the vector error correction model. Findings from the study, covering the period 1970 through to 2008, reveals that exchange rate pass-through to consumer prices in Nigeria is substantial. The evident large pass-through found was attributed to the continuous depreciation of the Naira over the whole sample observed. Firms and importers are therefore likely to perceive any increase in costs due to exchange rate depreciation as persisting and therefore, pass on to consumers most of the resultant increases in costs. Further, they argued that reasons for high exchange rate passthrough include the high and persistent inflation during the period under review as well as the high share of imports in the Nigeria consumption basket.

Also, Imimole and Enoma (2011) [20] in their work examined exchange rate depreciation and inflation in Nigeria. Their work covered the period of 1986-2008, using the Autoregressive Distributed Lag Bounds Test cointegration procedure. The results they obtained from the study showed that inflation in Nigeria is highly responsive to exchange rate depreciation, money supply and real gross domestic product. A long run relationship was also found to exist between inflation and exchange rate depreciation, indicating that the model has a self-adjusting mechanism for correcting any deviation of the variables from equilibrium. The implication of this is that additional efforts need to be put in place to increase the volume of export products to make up for the extra demand that may be created by the depreciation. The paper also found that inflation rate in Nigeria has a lagged cumulative effect. They conclude that although exchange rate depreciation may not directly control inflation, it helps to restructure the price mechanism of both import and export, such that Naira depreciation subtly tends to moderate prices in Nigeria, especially imported price inflation. In the same vein they recommended that policy makers should not totally rely on this instrument to control inflation, but should use it to complement other macro-economic policies. More so, policies should be put in place to increase domestic production of export commodities, which are currently shortsupplied.

Nevertheless, Sanusis (2014) [21] uses structural vector autoregression (SVAR) model for the Ghanaian economy to estimate the pass-through effects of exchange rate changes to consumer prices. The model incorporates the special features of the Ghanaian economy, especially its dependence on foreign aid and primary commodity exports for foreign exchange earnings. The findings show that the pass-through to consumer prices, although incomplete, is substantially large. This suggests that exchange rate depreciation is a potentially important source of inflation in Ghana. Using variance decomposition analyses, it is found that monetary expansion has been more important in explaining Ghana's actual inflationary process than the exchange rate depreciation.

In addition, Egwaikhide, Chete, And Falokun, (1994) [22] examined the quantitative effects of exchange rate depreciation on inflation, government revenues and expenditures, and money supply in Nigeria from 1973 1989. using VAR structural equations on cointegration. They find evidence from trend that exchange rate appears to correlate with inflation more when compared. The results of inflation equation demonstrate that official exchange rate is a significant determinant of price inflation, with a lag period of one year. Inadequate output and monetary expansion also featured prominently in this equation. But the coefficient of the expected rate of inflation, though positive, is not statistically significant even at the $10 \%$ level. The magnitude of external debt in local currency, which also depends on the exchange rate, has a tendency to increase debt service payments and, therefore, total expenditures, through a feedback mechanism using an error-correction term. All this has implications for budget deficit and growth in domestic money supply and thus inflation.

Thus in concluding the review of literature, it has become obvious that previous studies touched exchange rates devaluation on disaggregated variables such as effects on inflation, economic growth, government deficit spending. This study aims at taking more variables and a longer period. To the knowledge of the researcher, these gaps exist in the literature.

\section{Model Specification}

The choice of variables and their ordering for the SVAR model specification for this study was influenced by the earlier work of Abdulrasheed, George and Sanusi (2013) [2]. The SVAR specify for this study contains four variables. These are the natural the log of real exchange rate (RER), log of inflation (INF), log of budget deficit (BDF) and log of money supply (M2). The variables are expressed in logarithms to correct for heteroscedasticity. The endogenous variables are systematically ordered in order to properly capture the systematic shocks on exogenous variable. Exchange rate was ordered first, inflation ordered second, budget deficit third and money supply fourth. Money supply M2 is included in the model to allow for the effect of monetary policy in response to a large swing of the exchange rate or devaluation. In line with Abdulrasheed, George and Sanusi (2013) [2] the VAR model for the study is specify as:

$$
\mathrm{A}(\mathrm{L}) \mathrm{Xt}=\mathrm{et}
$$

Where;

$$
\mathrm{A}(\mathrm{L})=\mathrm{X}_{\mathrm{t}}
$$

$\mathrm{Xt}=$ column vector of endogenous variables.

$$
e_{t}=\left(e_{t} \text { rer, } e_{t} \text { inf, } e_{t} \text { bdf, } e_{t} m 2\right)
$$

$\mathrm{e}_{\mathrm{t}}=$ shocks associated with all the variables. They are residuals obtained from unrestricted SVAR. 


\subsection{Technique of Data Analysis}

The unit root property of the time series data was investigated to avoid estimation of spurious regression and ensures efficacy of the results. By definition, a series is stationary if it has a constant mean and a constant variance and/ or covariance. On the contrary, a non-stationary series contains a clear time trend and has a variance that is not constant overtime. Although there are a number of methods used to test for stationarity and the presence of unit roots, the method used in this study is the Kwiatkowski-PhillipsSchmidt-Shin's (KPSS) and Philllips-Perron (PP) tests. The choice of KPSS and PP was to overcome the problems associated with augmented dickey-fuller (ADF). Zivot and Andrews (1992) [23] note that the ADF test suffer from high size distortion while KPSS is robust in the midst of serial correlation and hetersocedasticity.

\subsubsection{KPSS Unit Root}

The KPSS unit root model is specified as:

$$
\Delta \mathrm{X}=\gamma 0+\gamma 1+\gamma 2 \mathrm{Xt}-1+\sum_{k=0}^{n} \lambda \Delta \mathrm{x}+\mu \mathrm{t}
$$

Where;

$\gamma 0, \gamma 1, \gamma 2, \lambda=$ parameters to be estimated $\mu \mathrm{t}=$ the error term.

\subsubsection{Phillips-Perron Test of Stationarity}

The Phillips-Perron (PP) test was carried out to test for the existence of a unit root in the time series. Usually, the unit root is conducted on individual variables and stated in three possible forms. The forms are model without intercept and trend, model with intercept but no trend and model with intercept and trend. The equations unit root equations are specified as shown below:

$$
\Delta \mu_{\mathrm{i}}=\beta \mu_{\mathrm{i}-1}+\beta \sum_{i=1}^{3} \Delta \mu \mathrm{i}-1+\mu_{1 \mathrm{i}}
$$

$\mu_{1 \mathrm{i}}=(\mathrm{INF}, \mathrm{BDF}, \mathrm{M} 2$ and RER) representing the variables used for the unit root test.

\subsubsection{Co-Integration Test for Long-Run}

Co-integration is a technique use in econometrics for testing whether or not the variables have a long-run relationship. The existence of co-integration relate to the existence of a long run equilibrium relationship among a set of non-stationary variables. There are certain advantages of this approach. First, the short- and long- runs parameters are estimated simultaneously. Secondly, it can be applied irrespective of whether the variables are integrated of order zero i.e., I (0) or integrated of order one i.e. I (1) (Amarawickrama and Hunt, 2008) [24]. Therefore, the need to pre-test for properties of the series associated with the other forms of co-integration analysis is not necessary. The relationship between the variables will be based on a VAR model of order $\mathrm{p}$ expressed as:

$$
\mathrm{Y}_{\mathrm{t}}=\mathrm{A}_{\mathrm{t}} \mathrm{Y}_{\mathrm{t}-1}+\ldots \ldots \ldots \ldots+\mathrm{A}_{\mathrm{p}} \mathrm{Y}_{\mathrm{t}-1}+\mathrm{B}_{\gamma}+\mathrm{e}_{\mathrm{t}}
$$

Where;

$\mathrm{Y}_{\mathrm{t}}=$ dimensional vector of non-stationary I (1) variable

$\gamma=\gamma$-dimensional vector of deterministic variable

$\mathrm{e}_{\mathrm{t}}=$ stochastic error residual

\subsubsection{Unrestricted Error Correction Model (UECM) for Short-Run}

The Unrestricted Error Correction Model (UECM) is an improvement on the traditional Error Correction Model (ECM) which is the process of reconciling the long-run and short-run equilibrium relationship of a time series as earlier revealed by the cointegration test. This study will adopt the (UECM) developed by Pesaran (2001) [25] and employed by Akinboade et al (2008) [18]. The model is stated as follows:

$$
\Delta R E R t=\alpha_{0}+\sum_{i=0}^{n} \alpha_{1} \Delta I N F_{t}+\sum_{i=0}^{n} \alpha_{2} B D F_{t}+\alpha 3 \mathrm{M} 2+\mu t
$$

Where;

$\Delta=$ difference operator

$\mathrm{e}_{\mathrm{t}}=$ error correction term

$\alpha_{0}=$ vector of the intercept

$\alpha_{j}=$ vector of the partial slopes $(j=1,2 \ldots .4)$.

$\mathrm{n}=$ maximum lag length

Other variables are as defined earlier.

The unrestricted error correction model (UECM) bounds testing approach to co-integration depends upon the tabulated critical values by Pesaran et al (2001) [25] to take the decision about the existence of co-integration among the variables. In case where, long run liaison is established and F-statistic indicates which variable should be normalized. However, if long run relationship exists, short run behavior is investigated using error correction method (ECM) as given below in equation (7):

$$
\Delta R E R t=\alpha_{0}+\sum_{i=0}^{n} \alpha_{1} \Delta I N F_{t}+\sum_{i=0}^{n} \alpha_{2} B D F t+\sum_{i=0}^{n} \alpha 3 M 2 t+\delta E C M t+\varepsilon t
$$

The residual term $\left(\mathrm{ECM}_{\mathrm{t}}\right)$ in equation (7) indicates the changes in dependent variable. These changes are not only due to the two levels of disequilibrium in the cointegration association but also in the other explanatory variables which points to the convergence of the dependent variable from short to long runs equilibrium (Masih and Masih, (1996) [26]. In such situation, the error correction term causes the dependent variable to converge to the long span of time for stable equilibrium caused by the variations in the independent variables.

\subsection{A priori Expectation}

This referred to the sign and sizes of the economic relationship among the variables of the model based on theoretical criteria. The expectations for equation (3.9) are that $\alpha_{1}<0, \alpha_{1}<0 \quad \alpha_{3}>0$. If however the estimates of the parameters turn up with signs not conforming to the a priori 
expectation, they should be rejected unless there is sufficient empirical reason to justify the abnormality. In general if these criteria are not met, that may suggest that the estimates are unsatisfactory.

\section{Presentation of the Empirical Results}

Table 1 shows the summary of descriptive statistics for the data used in the study. The estimation software has automatically re-sized the sample by omitting two observations from the sample. It is evident from the result that
RER and M2 have positive and small mean values and small standard deviations, suggesting that the errors that may be due to these estimates are within the acceptable limit. However, INF and BDF have negative mean values though for INF, the mean value is small as expected. The standard errors for both INF and BDF are large. Also, the Jaque-Bera and its probability values reveal that only $\mathrm{M} 2$ is asymptotically normally distributed, but not RER, BDF and INF. Finally the results of skewness suggest that all the variables are negatively skewed. It could be infer from the result that the summary statistic (s) for the data series are fairly okay.

Table 1. Descriptive Statistics.

\begin{tabular}{lllll}
\hline & BDF & INF & M2 & RER \\
\hline Mean & -11.92343 & -0.092857 & 0.060286 & 1.150000 \\
Median & 0.000000 & 1.150000 & 42.38000 & 0.839000 \\
Maximum & 1413.820 & 32.37000 & -40.18000 & 59.31000 \\
Minimum & -1452.320 & -43.44000 & 1.633936 & -125.4490 \\
Std. Dev. & 349.4574 & 15.70530 & -0.111908 & 4.215954 \\
Skewness & -0.066405 & -1.044722 & 3.442531 \\
Kurtosis & 17.12892 & 4.777453 & 0.358643 \\
Jarque-Bera & 291.1476 & 10.97413 & 0.835837 \\
Probability & 0.000000 & 0.004140 & 2.110000 \\
Sum & -417.3200 & -3.250000 & 9077.142 \\
Sum Sq. Dev. & 4152097. & 8386.322 & 32098 \\
Observations & 35 & 35 & 35 & 17.8339 \\
\hline
\end{tabular}

Source: e-views 9 output.

Table 2. Unit Root Test; $H_{0 k}:$ the data is stationary; $H_{0 p}$ : the data is not stationary.

\begin{tabular}{|c|c|c|c|c|c|c|}
\hline Variables & KPSS Levels & KPSS Difference & Remarks & PP Levels & PP Difference & Remarks \\
\hline INF & $0.218 *$ & ---------- & $\mathrm{I}(0)$ & $-6.022 *$ & ---------- & $\mathrm{I}(0)$ \\
\hline BDF & 0.500 & $0.397^{*}$ & I (1) & -1.283 & $-3.345^{*}$ & I (1) \\
\hline M2 & $0.092 *$ & --------- & $\mathrm{I}(0)$ & $-7.972 *$ & --------- & $\mathrm{I}(0)$ \\
\hline RER & $0.145 *$ & --------- & $\mathrm{I}(0)$ & $-5.575^{*}$ & ---------- & $\mathrm{I}(0)$ \\
\hline
\end{tabular}

KPSS Critical Value at $5 \%=0.463$;

PP Critical Value at $5 \%=-2.96$.

* indicates significant at $5 \%$.

$H_{0 k}:$ null hypothesis for KPSS

$H_{0 P}$ : null hypothesis for $P P$.

Source: e-views 9 output.

The study uses the Kwiatkowski-Phillips-Schmidt-Shin's (KPSS) and Phillips-Perron (PP) unit root tests to check the stationarity of the data set. The choice of KPSS and PhillipsPerron (PP) were to overcome the problems associated with augmented dickey-fuller (ADF) unit root test option. Zivot and Andrews (1992) [23] note that the ADF suffers from high size distortion while KPSS is robust in the midst of serial correlation and hetersocedasticity. In selecting lag length for the KPSS and PP tests, the method of "general-tospecific" Schwartz information criterion was adopted. By this method, the maximum lag length option available in E-views statistical software is left blank while allowing Schwartz information criterion as automatic selection. The KPSS and PP results are reported in table 2. With the exception of budget deficit (BDF), both tests indicate that all the variables are $I(0)$.

The finding that one of the variables is I (1) and the others are I (0) implies that the variables are not integrated of the same order. This result does not meet the necessary condition for the test of co-integration. As Johansen (1991) noted, cointegration test becomes necessary only when all the variables are I (1). However, on the contrary, Pesaran (1999, 2001) posits that even when the variables are integrated of different orders, (ie some I (1) and others I (0)) co-integration test is still necessary as long as none of the variables is I (2). The order of integration reported in table 2 also satisfies the condition for estimating the unrestricted VAR in first difference. 
Table 3. Selection of Lag length for Co integration Test.

\begin{tabular}{lllllll}
\hline Lag & Log L & LR & FPE & AIC & SC \\
\hline 0 & -676.2927 & NA & $9.46 \mathrm{e}+12$ & 41.22986 & 41.41125 \\
1 & -635.4543 & $69.30141^{*}$ & $2.12 \mathrm{e}+12^{*}$ & $39.72451^{*}$ & 41.29089 \\
2 & -629.1637 & 9.150019 & $4.00 \mathrm{e}+12$ & 40.31295 & $40.63148^{*}$ & 41.94551 \\
3 & -611.0921 & 21.90502 & $3.99 \mathrm{e}+12$ & 40.18740 & $40.02967 *$ & 42.54553 \\
\hline
\end{tabular}

* indicates lag order selected by the criterion.

LR: sequential modified LR test statistic (each test at 5\% level).

FPE: Final prediction error.

AIC: Akaike information criterion.

SC: Schwarz information criterion.

HQ: Hannan-Quinn information criterion.

Source: estimated using e-views 9.

Lag selection test was carried out to determine the optimal lag for the test of co-integration. Although there are many tests for optimal lag selection such as (the traditional criteria (AIC, SIC, HQ, LR, FPE)), the multivariate generalization of AIC from the empirical VAR in level, and finally, the Sim's LR statistic) this study uses the traditional criteria reported in table 3 for the test of co-integration. All the traditional information criteria suggest an optimal lag 1 for the test of co-integration. Consequently, this study uses a lag length of two for the test of co-integration.

Table 4. Result of Test for Co-integration Rank.

\begin{tabular}{lllll}
\hline No. of CE $(\mathbf{s})$ & $\boldsymbol{\lambda}_{\text {Trace }}$ & $\mathbf{5 \%}$ & $\boldsymbol{\lambda}_{\text {max }}$ & $\mathbf{5 \%}$ \\
\hline None ${ }^{*}$ & 53.48 & 47.86 & 23.27 & 27.58 \\
At most $1 *$ & 30.21 & 29.80 & 17.62 & 21.13 \\
At most 2 & 12.59 & 15.49 & 10.87 & 14.26 \\
At most 3 & 1.715 & 3.841 & 1.715 & 3.841 \\
\hline
\end{tabular}

Trace test indicates 2 cointegrating eqn (s) at the 0.05 level. Max-eigenvalue test indicates 2 cointegrating eqn (s) at the 0.05 level. * denotes rejection of the hypothesis at the 0.05 .

$\lambda_{\text {Trace }}=$ Trace Statistic.

$\lambda_{\text {max }}=$ Maximum eigenvalue.

Source: estimated using e-views 9.

The test for co-integration among RER, BDF, INF and M2 using the Johansen approach suggests that there is evidence of co-integration. This is true from both the maximum eigenvalue and trace statistics, when trend is not included in the cointegrating equation. Based on the result, the variables of the study have long-run equilibrium relationship which keeps them in proportion to each other over the study period. It is also evident from the co integration results that there is no presence of full rank since the subtraction of the number of co integrating equations and the variables under study do not equal to zero, implying that the model is good and in functional form.

Table 5. Long-run Normalized co-integrating coefficients.

\begin{tabular}{|c|c|c|c|c|}
\hline Panel A: exchange rate Pass-through to BDF & $\begin{array}{l}\text { LINF } \\
1.00000\end{array}$ & $\begin{array}{l}\text { LBDF } \\
-0.30451 \\
(1.6891)\end{array}$ & $\begin{array}{l}\text { LM2 } \\
-1.367305 \\
(2.10130)\end{array}$ & $\begin{array}{l}\text { LRER } \\
0.149723 \\
(0.53187) \\
{[2.8037]}\end{array}$ \\
\hline Panel B: exchange rate Pass-through to INF & $\begin{array}{l}\text { LINF } \\
1.00000\end{array}$ & $\begin{array}{l}\text { LBDF } \\
-3.28399 \\
(0.6597)\end{array}$ & $\begin{array}{l}\text { LM2 } \\
4.490230 \\
(6.81602)\end{array}$ & $\begin{array}{l}\text { LRER } \\
-0.491689 \\
(1.73950) \\
{[-0.28339]}\end{array}$ \\
\hline
\end{tabular}

( ) denotes estimated standard errors.

[ ] denotes estimated t-values.

Source: estimated using e-views 9 .

Table 5 shows the long-run pass-through effect from exchange rate to budget deficit and inflation over the study period. Exchange rate pass-through to BDF is shown in panel A while exchange rate pass-through to INF is shown in B. The result shows that the long-run exchange rate passthrough elasticity to BDF is positive and significant and about 15 per cent while the long-run exchange rate pass- through elasticity to INF is negative, insignificant and is about 49.2 per cent. These results indicate that pass-through to both BDF and INF is incomplete. The negative passthrough to inflation is as expected. It suggests that an appreciation of naira by one unit decreases inflation by about 49 per cent over the study period. This finding agrees with Ivohasina (2012) [27]. 
Table 6. Estimated Short-run Elasiticities of Pass-through Effect.

\begin{tabular}{|c|c|c|c|c|c|}
\hline Period & $\Delta$ LRER & $\Delta$ LBDF & $\Delta$ LINF & $\Delta \mathrm{LM} 2$ & $\mathbf{E M C}_{\mathrm{t}}$ \\
\hline \multirow{3}{*}{1} & 0.050752 & -0.050752 & -0.105110 & -0.305826 & -0.021572 \\
\hline & $(0.01935)$ & $(0.01935)$ & $(0.02988)$ & $(0.10314)$ & $(0.00536)$ \\
\hline & [2.62284] & {$[-2.62284]$} & {$[-3.51773]$} & {$[-2.96515]$} & {$[-4.0 .2425]$} \\
\hline \multirow{3}{*}{2} & 0.077072 & 0.274908 & -0.905916 & -1.807675 & -0.241972 \\
\hline & $(1.73789)$ & $(0.20320)$ & $(2.68363)$ & $(2.72246)$ & $(0.04816)$ \\
\hline & {$[0.04435]$} & [ 1.35288$]$ & {$[-0.33757]$} & {$[-0.66399]$} & {$[-5.02439]$} \\
\hline \multicolumn{6}{|l|}{ Diagnostic } \\
\hline Test & & Statistics & & P-values & \\
\hline R-squared & & 0.629 & & & \\
\hline LM test & & 15.63 & & 0.479 & \\
\hline $\mathrm{ARCH}$ test & & 2.368 & & 0.210 & \\
\hline Jacque-Bera & & 5.130 & & 0.769 & \\
\hline
\end{tabular}

Source: estimated using e-views 9.

The short-run elasticities of pass-through are presented in Table 6. The coefficients of the error correction terms are 0.02 and 0.24 for first and second periods respectively and are highly statistically significant. This suggests that any deviation from the long-run equilibrium relationship is adjusted by about 25 per cent, on the average, over the period under study. Thus, it will take roughly 25 periods for the variables of the study to adjust to their long-run equilibrium. However this speed of adjustment is quite low.

The short-run exchange rate pass-through elasticities are found to be 0.051 and 0.07 for the first and the second periods respectively and significant in the first period but insignificant for the second period. Exchange rate pass-through to inflation is negative both in the first and the second periods with elasticities of about 11 per cent and 91 per cent respectively. While the estimate is significant in the first period, it is not significant in the second period of the analysis. For budget deficit however, pass-through is negative in the first period but positive in the second period. The elasticities are about 5 per cent and 27 per cent respectively. What is worthy of note is that exchange rate pass-through to inflation is higher in than pass-through to budget deficit in Nigeria over the study period. One reason that may account for high exchange rate pass-through to inflation, as Abiodun Ajibola, Inuwa, Idowu, Sani, Anigwe and Udoko (2016) [28] observed, is that the composition of the CPI basket indicates that about two-third of goods and services included in the CPI basket were produced in the country, leaving only the balance of about one-third being imported. CPI on food alone constituted about 50 per cent of the total CPI. Consequently, the pass-through effect impacted mainly on those commodities imported, as foreign exchange is required to import them.

The result of diagnostic statistic (s) fitted the model fairly well. The R-square of the model shows that about 62 per cent of the variation in dependent variable is explained by the combined effects of all the dependent variable used in the study, suggesting that about 38 per cent variation in dependent is accounted for by other factors not included in the model.

From the table 6, the LM test has an insignificant probability value which suggests evidence of absence of autocorrelation in the error residuals of the data set. Similarly, the probability of the $\mathrm{ARCH}$ test which is 0.210 implies that the residuals of the series data are homoscedastic and are not suffering the problem of heteroscedasticity. However, the result failed the test of normalilty as indicated in table 9.

\subsection{Estimated System of Shocks from Structural Vector Auto-Regression (SVAR)}

Structural VAR was used to estimate the shocks from exchange rate to other variables of the study. They are derived from the estimated residuals from the unrestricted VAR using the structural factorization described in section 3.4 Figures in parenthesis are the $p$-values. The coefficients of the structural shocks (\&i) are their respective standard deviations. The estimated SVAR results are shown in equation 9 to 12 below.

$$
\begin{aligned}
& \mathrm{e}^{\mathrm{inf}}=0.43 \varepsilon^{\mathrm{inf}} \\
& \text { (0.021) } \\
& \mathrm{e}^{\mathrm{m} 2}=0.06 \mathrm{e}^{\mathrm{inf}}+0.08 \varepsilon^{\mathrm{m} 2} \\
& \text { (0.31) (0.00) } \\
& e^{\text {rer }}=-0.44 e^{\text {inf }}-0.48 e^{\mathrm{m} 2}+0.033 \varepsilon^{\text {rer }} \\
& (0.23)(0.04)(0.00) \\
& \mathrm{e}^{\mathrm{bdf}}=0.035 \mathrm{e}^{\mathrm{inf}}+0.054 \mathrm{e}^{\mathrm{m} 2}+0.272 \mathrm{e}^{\mathrm{rer}}+0.018 \varepsilon^{\mathrm{bdf}} \\
& (0.03)(0.23)(0.00)(0.00)
\end{aligned}
$$

Form the results in equation 9 to 12 , the contemporaneous relationship among the variables in the system suggest that all the coefficients are correctly signed. For example, the coefficient of $\mathrm{e}^{\mathrm{inf}}$ in equation 11 implies that appreciation in naira by one unit is associated with fall in the elasticity of inflation by about 44 units while the coefficient of $\mathrm{e}^{\mathrm{rer}}$ in equation 12 implies that appreciation in naira by one unit is associated with an increase in the elasticity of budget deficit by about 27 units. However, the full impact of exchange rate changes on inflation and budget deficit are given by the 
accumulated impulse response function (IRF) given in table 5 , table 6 and table 7 .

\subsection{Impulse Response Functions (IRFs)}

Impulse response functions trace the effect of a shock emanating from an endogenous variable to other variables in normalized model. IRFs from SVAR are used in this study to assess the pass-through from real exchange rate (RER) to BDF, INF and M2. The IRFs trace out the effect over time on a structural one standard deviation shock to the exchange rate equation. Normalizing the accumulated impulse responses of INF, BDF and M2 to RER shocks by the accumulated responses allows identifying the pure effects of RER shocks. The results are shown in table 7 , table 8 and table 9 .

Table 7. Response of BDF to RER.

\begin{tabular}{lllll}
\hline Period & M2 & INF & BDF & RER \\
\hline 1 & -13.46139 & -11.14646 & 233.8344 & 0.000000 \\
2 & 14.93477 & -4.590226 & -79.12937 & -7.661765 \\
3 & 31.68425 & 11.36975 & -34.38484 & -3.131196 \\
4 & 12.58949 & 4.114529 & 46.11481 & -6.775006 \\
5 & 16.58645 & 1.853679 & 7.761648 & -6.318646 \\
6 & 20.11044 & 4.779015 & -5.453081 & -5.760038 \\
7 & 18.20490 & 4.569531 & 11.06565 & -5.928591 \\
8 & 17.52858 & 3.712403 & 9.691651 & -6.115459 \\
9 & 18.42516 & 4.062761 & 5.043369 & -5.974446 \\
10 & 18.30942 & 4.213050 & 6.963834 & -5.973755 \\
\hline
\end{tabular}

Source: estimated using e-views 9.

Table 7 presents the response of budget deficit (BDF) to percentage change in exchange rate. The result shows that exchange rate pass-through (ERPT) to BDF was negative from the $2^{\text {nd }}$ to the $10^{\text {th }}$ period. A one percent positive shock in exchange rate leads to about -7.66 declines in budget deficit in the $1^{\text {st }}$ period, rises to about -3.13 in the $3^{\text {rd }}$ period declined again to about -5.76 in the $6^{\text {th }}$ period and declined further to -5.97 in the $10^{\text {th }}$ period. These results indicate that in Nigeria, ERPT to budget deficit is has been increasing and decreasing but increases more slowly than it decreases. In both cases, however, the passthrough is incomplete. This is in conformity with Rafindadi et al (2010) [10] and Abdulrasheed, George and Rafindadi (2013) [2].

Table 8. Response of INF to RER.

\begin{tabular}{lllll}
\hline Period & M2 & INF & BDF & RER \\
\hline 1 & -2.983028 & 16.04756 & 0.000000 & 0.000000 \\
2 & 1.626706 & 16.68518 & 0.817681 & -1.611744 \\
3 & 0.773680 & 16.79653 & 1.618492 & -2.161401 \\
4 & 1.109631 & 16.76300 & 2.084277 & -2.086059 \\
5 & 1.012638 & 16.76653 & 1.559953 & -2.138572 \\
6 & 1.090381 & 16.79218 & 1.674543 & -2.113300 \\
7 & 1.039554 & 16.77940 & 1.769128 & -2.126475 \\
8 & 1.056069 & 16.77749 & 1.716542 & -2.122345 \\
9 & 1.056606 & 16.78137 & 1.698555 & -2.122964 \\
10 & 1.055435 & 16.78101 & 1.723147 & -2.122668 \\
\hline
\end{tabular}

Source: estimated using e-views.
Table 8 presents the response of inflation (INF) to percentage change in exchange rate. The result shows that exchange rate pass-through (ERPT) to INF was negative from the $2^{\text {nd }}$ to the $10^{\text {th }}$ period. In the $2^{\text {nd }}$ period, -1.61 per cent exchange rate shock is pass-through to inflation, decreases to -2.14 in the $5^{\text {th }}$ period and increases slightly to 2.12 in the $10^{\text {th }}$ period.

Comparing the pass-through from exchange rate to budget deficit and to inflation, the speed and size of pass-through to inflation is lower in budget deficit than in inflation. This suggests that budget deficit is most likely affected by other factors than exchange rate in Nigeria over the period of study. This also implies that inflation responds significantly to exchange rate shocks in Nigeria. This result agrees with Fatai and Akinbobola (2015) [18] that in Nigeria, consumer price (inflation) responds significantly to shocks in oil price index and money supply, implying that the country is vulnerable to international price shocks (imported inflation). However, the finding is not in support of study by Seyed, Majid Maryam and Zhila (2015) [28]

Table 9. Response of M2 to RER.

\begin{tabular}{lllll}
\hline Period & M2 & INF & BDF & RER \\
\hline 1 & 15.98722 & 0.000000 & 0.000000 & 0.000000 \\
2 & 10.44177 & -0.154833 & 4.882441 & -1.635899 \\
3 & 12.04222 & -0.432650 & 6.030706 & -1.094853 \\
4 & 11.62909 & -0.355876 & 3.226408 & -1.312842 \\
5 & 11.95331 & -0.242162 & 4.175444 & -1.191919 \\
6 & 11.69419 & -0.323598 & 4.578874 & -1.259169 \\
7 & 11.79546 & -0.323661 & 4.219466 & -1.235646 \\
8 & 11.79421 & -0.301928 & 4.182857 & -1.238795 \\
9 & 11.78347 & -0.307459 & 4.318301 & -1.238270 \\
10 & 11.77888 & -0.313057 & 4.280790 & -1.240301 \\
\hline
\end{tabular}

Source: estimated using e-views.

Table 9 shows the response of M2 to real exchange rate shocks. Results from responses over different time horizon indicate that $\mathrm{M} 2$ reacted negatively to the shocks in exchange rates for the $2^{\text {nd }}$ period to the $10^{\text {th }}$ period. In terms of magnitudes and sizes of the responses, passthrough is higher in M2 than in BDF and INF over the study period though, incomplete. This supports the findings of Festus and Gabriel (1994) [29] that passthrough was higher in money supply than in consumer prices and budget deficit in Nigeria.

\subsection{Variance Decomposition (VDC)}

The variance decompositions break down the forecast variance of endogenous variables into components that can be attributed to each of the various shocks to the system. It allow the study to examine the relative importance of the various shocks for endogenous variables in the model. See table 10 below. 
Table 10. Variance Decomposition of $B D F$.

\begin{tabular}{llllll}
\hline Period & S. E. & M2 & INF & BDF & RER \\
\hline 1 & 234.4867 & 0.329567 & 0.225963 & 99.44447 & 0.000000 \\
2 & 248.0892 & 0.656812 & 0.236097 & 99.01171 & 0.095377 \\
3 & 252.7322 & 2.204587 & 0.429888 & 97.25827 & 0.107254 \\
4 & 257.3353 & 2.365764 & 0.440211 & 97.02126 & 0.172765 \\
5 & 258.0701 & 2.765389 & 0.442867 & 96.56001 & 0.231731 \\
6 & 259.0181 & 3.347998 & 0.473674 & 95.89884 & 0.279490 \\
7 & 260.0005 & 3.813006 & 0.500989 & 95.35663 & 0.329376 \\
8 & 260.8689 & 4.239151 & 0.517911 & 94.86080 & 0.382143 \\
9 & 261.6672 & 4.709146 & 0.538863 & 94.32005 & 0.431946 \\
10 & 262.5012 & 5.165774 & 0.561203 & 93.79203 & 0.480994 \\
\hline
\end{tabular}

Source: estimated using e-views.

The VDC analysis in table 8 shows that in the first period, a shock to the exchange rate contributes 99.4 per cent variation to the BDF series, while INF and M2 have only 0.23 and 0.33 per cent contributions respectively. After first period, the shock of exchange rate to BDF decreases to 96.6 per cent in period five, while that of INF and M2 increases to 0.44 and 2.77 per cent respectively.

The contribution of exchange rate in the variation of BDF is high compared to its contribution in the variation of inflation (INF) and of money supply (M2) suggesting a significant inertia for inflation process and money supply in Nigeria. This finding is consistent with the result of impulse response functions.

\subsection{Discussion of Findings}

Findings from this study reveal that, over the study period, exchange rate pass-through in Nigeria is incomplete both in the short-run and in the long-run. This is also evident from the results of impulse response functions and variance decomposition. One reason for slow exchange rate passthrough, as Abdulrasheed, George and Rafindadi (2013) [2] observe is that exporters to Nigeria practice a substantial degree of pricing-to-market strategy. Instead of allowing the naira price of their products to vary whenever there are changes in the exchange rate, these firms allow their markups to vary as they change their local currency prices in the opposite direction of the change in exchange rate.

For inflation, pass-through elasticities are higher in the short-run (about 90 per cent) than in the long-run (about 14 per cent). This finding corroborates Abiodun Ajibola, Inuwa, Idowu, Sani, Anigwe and Udoko (2016) [28] but contrast Aliyu (2010) [10]. On the basis, the first null hypothesis $\left(\mathrm{H}_{\mathrm{O} 1}\right)$ that real exchange rate does not pass-through to domestic prices in the Nigerian economy over the period of study is rejected and the alternative hypothesis is accepted. Hence, the first specific research question for this study is said to have been answered.

Unlike exchange rate pass-through to inflation, passthrough elasticities from exchange rate to budget deficit are higher in the long-run (about 15 per cent) than in the shortrun (about 5 per cent). However, like pass-through to inflation, exchange rate pass-through to budget deficit is incomplete and low. On this basis, the second null hypothesis $\left(\mathrm{H}_{02}\right)$ that real exchange rate does not pass-through to budget deficit in the Nigerian economy over the period of study is rejected in favour of the alternative hypothesis. Therefore, the study could be said to have answered the second research question.

The co-integration test reveals the existence of two cointegrating equations with its eigenvalue and trace statistics greater than critical values at 5 percent. This suggests that the variables of the study have a long-run equilibrium relationship. On this basis, the third null hypothesis $\left(\mathrm{H}_{03}\right)$ that a long relationship does not exist among RER, inflation, and budget deficit over the period of study is rejected and the alternative accepted. Similarly, the coefficient of the error correction model is consistent with the expected negative value, indicating that there is feedback adjustment from short-run to long-run equilibrium among variables of the study. However, the speed of adjustment in restoring the system to equilibrium in the long run is low.

\section{Conclusion and Recommendations}

This study has shown that, over the study period, exchange rate pass-through in Nigeria is low, partial and incomplete both in the short-run and in the long-run. On average, a 10 per cent appreciation of the naira currency will brings about a 3 percent decrease in inflation and 5 percent decrease in budget deficit. Half of the increase occurs within the first period following the exchange rate change, and the full impact generally takes place within fifth. This is also evident from the results of impulse response functions and variance decomposition.

The reason for low pass-through of exchange rate could be attributed to the fact that exporters to Nigeria practice a substantial degree of pricing-to-market strategy. They do not allowed naira price of their products to vary with changes in the exchange rate. What they do is to vary prices of products to vary with changes in local currency prices in the opposite direction of the change in exchange rate. This practice affects the strength of naira currency in Nigeria. Despite this however, finding from the study shows that exchange rate pass-through to inflation is higher in the short-run (about 90 per cent) than in the long-run (about 14 per cent).

For budget deficit however, exchange rate pass-through elasticities from exchange rate to budget deficit are higher in the long-run (about 15 per cent) than in the short-run (about 5 per cent). However, like pass-through to inflation, exchange rate pass-through to budget deficit is incomplete and low. However, the response of broad money supply (M2) to real exchange rate shocks has been negative. Results from impulse response functions over different time horizon indicate that $\mathrm{M} 2$ reacted negatively to the shocks in exchange rates for the $2^{\text {nd }}$ period to the $10^{\text {th }}$ period. In terms of magnitudes and sizes of the responses, pass-through is higher in M2 than in BDF and INF over the study period though, incomplete. This supports the findings of Festus and Gabriel (1994) [29] that pass-through was higher in money supply than in consumer prices and budget deficit in Nigeria. A major implication of incomplete exchange rate pass-through 
is that the cost of true float may not be as large as it would under complete pass-through. This again, agrees with Aliyu et al (2013).

The findings from this study have a number of policy implications for Nigeria government. A major policy implication of the results of the study is that concerted effort should be made by the Nigeria's government to strengthen the production capacity of domestic firms and industries in order to reduce the level of the imported consumer and capital goods. This will help improve the level of exchange rate pass-through in Nigeria.

The role of money supply in exchange regime and in addressing inflationary tendency cannot be overlook. For example, the monetarist posit that inflation is, always and everywhere, a monetary phenomenon. Therefore, there is the need to pursue a stable monetary policy that neither fuels inflation nor creates an excess cashless economy. This is relevant to Central Bank of Nigeria given her task of achieving a stable exchange rate, through appropriate policies and interventions in the foreign exchange market and efficient management of foreign reserves.

Furthermore, to address the fear of pass-through and avoid large exchange rate-induced inflation, policy makers should improve the overall macroeconomic policies. For example, on the budget side, exchange rate depreciation significantly affects both the revenue and expenditure sides of the budget in Nigeria and it could enlarge the existing budget deficit if not properly managed. A restrictive monetary policy may be implemented to complement the existing exchange rate regime in Nigeria.

This study suffers two important limitations. First, the SVAR model employed in this study is highly aggregative and may not permit the endogeneity of the variables employed. Thus, findings from the model's results may be more suggestive than definitive. A more detailed modelling of the interactions between exchange rate, budget deficit and is therefore required. Therefore, further studies on a related topic may explore other methods of data analysis especially disaggregated models.

The second weakness has to do with the co-integration and error correction technique explored in the estimation of the structural equations. This methodology generally requires a large sample size to draw solid inferences for policy implications. The sample size of the current estimate (19802016) does not permit the study to have great confidence in the results obtained. Further studies may consider the possibility of extending the sample size backward to 1960 to see the robustness of the results.

\section{References}

[1] Abdul Rashid \& F. Husain, (2010). Capital Inflows, Inflation and Exchange Rate Volatility: An Investigation for Linear and Nonlinear Causal Linkages Pakistan. Institute of Development Economics Islamabad (PIDE) Working Papers; No. 63.

[2] Ajayi, S. Ibi \& K. Awosika (1980) 'Inflation in Nigeria: Domestic or Imported', commissioned paper for Productivity Prices and Incomes Board, January.
[3] Alum, T. (2012). Exchange rate and foreign interest rate linkage for Sub- Saharan Africa Floaters. IMF Working Paper.

[4] Alex. H. \& Innes. M. (2006). The relationship between interest rates and inflation in South Africa. Revisiting Fishers' Hypothesis. Euro Journals Publishers Inc.

[5] Alpanda, S., Kotze, K, \& Woglom, G. (2010). The role of the exchange rate in model for the South African economy. South African Journal of Economics. Vol. 78: 2.

[6] Asher O. J (2012). The Impact of Exchange rate Fluctuation on the Nigeria Economic Growth (1980-2010). /Unpublished B. sc Thesis of Caritas University Emene/, Enugu State, Nigeria.

[7] Bacchetta, P. \& van Wincoop, E. (2000). Does exchange rate stability affect trade and welfare? /American Economic Review/, 90, pp. 1093-1109.

[8] Banerjee, Anindya, Juan Dolado, John Galbraith, \& David F. Hendry (1993), Cointegration, Error Correction, and the Econometric Analysis of Non-Stationary Data. Oxford: Oxford University Press.

[9] Bergen, J. V. (2010). 6 Factor that Influence Exchange Rates. Investopedia,

http://www.investopedia.com/article/basic/04/050704.asp\#axz z288SmcagR.

[9] Bosworth, B. P., \&Collins, S. M. (1999) Capital flows to developing economies: Implications for saving and investment. In Brookings papers on economic activity no. 1. Brookings Institution., pp. 146-169.

[10] Carrera, J. \& Restout, R. (2008). Long-run determinant of real exchange rate in Latin- America, GATE (Grouped' Analysis de theory Economique) Working paper 08-11.

[11] Central Bank of Nigeria (2014). Annual Report and Statements of Account. Abuja: Central Bank of Nigeria.

[12] Canetti, E. \& J. Greene (1991) 'Monetary growth and exchange rate depreciation as causes of inflation in African countries: An empirical analysis', mimeo, IMF, Washington DC.

[13] Charles (1993). Real exchange rates and relative prices. An empirical investigation./Journal of Monetary Economics /32, pp. 35-50.

[14] Chhibber, A., J. Cottani, R. Firuzabadi, \& M. Walton, (1989), 'Inflation, price controls and fiscal adjustment in Zimbabwe', World Bank Working Papers, WPS 192, April.

[15] Clarida, R. \& Gali, J. (1994) "Sources of real exchange rate fluctuations. How important are nominal shock?" Carnegie-Rochester Conference Series on Public Policy 41: $1-56$

[16] Corden, W. M., 1989, 'Macroeconomic adjustment in developing countries', World Bank Research Observer, Vol. 4, No. 1, pp. 5 1-64.

[17] Ebiringa, O. T. \& A. B. Nnneka Exchange Rate, Inflation and Interest Rates Relationships: Autoregressive Distributed Lag Analysis. Journal of Economics and Development Studies June 2014, Vol. 2, No. 2, pp. 263-279.

[18] Edwards, Sebastian (1989). Real Exchange Rates, Devaluation and Adjustment: Exchange Rate Policy in Developing Countries. Cambridge, Mass: MIT Press. 
[19] Egwaikhide, F. O., L. N. Chete \& G. O. Falokun. (1994). Exchange Rate Depreciation, Budget Deficit and Inflation: The Nigerian Experience. AERC Research Paper No. 26. Nairobi: African Economic Research Consortium.

[20] Eichengreen, B., (2008). The Real Exchange Rate and Economic Growth. Commission on Growth and Development Working Paper No. 4.

[21] Enders, W (1995), Applied Econometric Times Series. Wiley: New York.

[22] Ezirim, C. B., Edith Azuka Amuzie and Michael I. Muoghalu (2012). Autoregressive Distributed Lag Analysis of Interdependencies Between Inflation and Exchange Rates in Sub-Saharan Nigeria. The IABPAD Conference Proceedings Dallas, Texas, Vol. 9, No. 2, April 19-22, 2012, pp. 1082-1093.

[23] Fadli, F., Abu H. A., Nurul S. B., Nurmadihah J., Zuraida M., Norazidah S. \& Kamaruzaman J. (2011). A Vector Error Correction Model (VECM) Approach in Explaining the Relationship Between Interest Rate and Inflation Towards Exchange Rate Volatility in Malaysia. World Appl. Sci. J., 12 (Special Issue on Bolstering Economic Sustainability): 49-56.

[24] Federal Republic of Nigeria, 1986, Structural Adjustment Programme, July 1986-June 1988, Government Printer, Lagos.

[25] International Monetary Fund, IMF (2011). International monetary fund-world economic outlook (Nigeria GDP Growth rate) accessed from www.indexmundi.com/factbook/countries/Nigeria/economy in February, 2015.

[26] Johansen, S. (1988)."Statistical Analysis of Cointegration Vectors". Journal of Economic Dynamics and Control. 12: 231-254.

[27] Johansen, S. (1991), "Estimation and Hypothesis Testing of Co-integration Vectors in Gaussian Vector Autoregressive Model". Econometrics, 59: 1551-80.

[28] Jhingan, M. L. (2003). Monetary Theory. Konark Publishers Pvt. Ltd.

[29] Keynes JM (1936). The general theory of employment, interest and money. London. Macmillan publication.
[30] Mbanefoh, G. F. (1993). "Elements of the Structural Adjustment Programme in Nigeria's: Public Expenditure Policies". The Nigerian Journal of Economic and Social Studies. 35 (2): 192-202.

[31] Mordi, C. N. O; E. A. Essien; A. O. Adenuga; P. N Omanukwue; M. C Ononugbo; A. A Oguntade; M. OAbeng; O. M Ajao (2007). The dynamics of inflation in Nigeria. Occasional paper No 32, Central Bank of Nigeria.

[32] Ndung'u, Njuguna (1993). "Dynamics of the Inflationary Process in Kenya." Goteborg, Sweden: University of Goteborg.

[33] Nucu. A. E. (2011). Relationship between exchange rate and key macroeconomic indicators. Case Study Romania The Romanian Economic Journal. XIV, no. 41: 127-145.

[34] Obadan, M. I (2004) Globalisation And Economic Management In Africa "Chapter One In: Nigeria Economic Society Paper For The 2003 Annual Conferences (Ibadan Nigeria Economic Society.

[35] Odedokun, M. O. (1996). "Dynamics of Inflation in SubSaharan Africa: The Role of Foreign Inflation; Official and Parallel Market Exchange Rates; and Monetary Growth." Dundee, Scotland: University of Dundee.

[36] Odusola, A. F. \& A. E. Akinlo (2001). "Output, Inflation, and Exchange Rate in Developing Countries: An Application to Nigeria”. The Development Economies XXXIX-2: 199-222.

[37] Ogundipe A. A., \& Egbetokun, S. (2013) Exchange Rate PassThrough To Consumer Prices In Nigeria. European Scientific Journal September 2013 edition vol. 9, No. 25.

[38] Pesarn, M. H, Shin, Y (1999), An autoregressive distributed lag modeling approach to cointegration analysis, \|Cambridge: Cambridge University Press, chapter 11 of Economic Theory in the 20th Century.

[39] Sanusi, A. R., (2010) "Exchange Rate Pass-Through to Consumer Prices in Ghana: Evidence from Structural Vector Auto-Regression" The West African Journal of Monetary and Economic Integration, Vol. 10, No. 1, June.

[40] Zhang, Y. (2000), "Real Exchange Rate-SVAR Analysis", bss.sfsu.edu/economics/faculty. 